\title{
(PRO)AKTIVITÁS EGY NEMZETKÖZI NAGYVÁLLALAT MAGYAR LEÁNYVÁLLALATÁNAK TÁRSADALMI FELELŐSSÉGVÁLLALÁSÁBAN
}

Szerző:

Lázár Tímea

Debreceni Egyetem

Bene Ágnes

Debreceni Egyetem

Első szerző e-mail címe:

lazar.timea@econ.unideb.hu

\section{Lektorok:}

Móré Mariann

Debreceni Egyetem Egészségügyi Kar

\author{
Ásványi Katalin \\ Budapesti Corvinus Egyetem
}

Mező Ferenc

Eszterházy Károly Egyetem

Mező Katalin

Debreceni Egyetem

Lázár Tímea, Bene Ágnes (2017): (Pro)aktivitás egy nemzetközi nagyvállalat magyar leányvállalatának társadalmi felelősségvállalásában. Különleges Bánásmód, III. évf. 2017/4. szám, 77-95. DOI 10.18458/KB.2017.4.77

\begin{abstract}
Absztrakt
A nemzetközi nagyvállatok magyarországi elterjedése, majd a magyar munkavállalók külföldi munkavállalása lehetővé tette a nemzetközi gyakorlatok fokozottabb megjelenését a szervezetek müködésének minden területén. Mivel a szervezetek világszerte folyamatos kihívásokkal szembesülnek, az ezen kihívásokra kifejlesztett és alkalmazott megoldások tárháza bővül. Jelen tanulmány egy német anyavállalat magyarországi leányvállalatának gyakorlatát tárja fel a fogyatékosokkal és megváltozott munkaképességü személyekkel kapcsolatban. Ezen tevékenységek nagyrészt a humánerőforrás gazdálkodással (HR), a kommunikációval, és a vállalat társadalmi felelősségvállalásával (CSR) hozhatók összefüggésbe. A tanulmányban a vállalat konkrét gyakorlata kerül bemutatásra, az új elemek komplexitásának hangsúlyozásával.
\end{abstract}

Kulcsszavak: Interkulturális, HR, CSR, fogyatékos, jó gyakorlat, összetett

Diszciplina: közgazdaságtan

\begin{abstract}
The spread of international companies in Hungary and the employment of Hungarian workers abroad have made it possible for foreign practices to increasingly appear in every field of the organizations' functions. As organizations face continuous challenges all over the world, the range of solutions developed and used to tackle these challenges broadens continually. This paper describes the practice of a Hungarian subsidiary owned by a German parent company towards people with disabilities and those whose work capacity has changed.
\end{abstract}


These activities are in connection with Human Resources, Communication, and more generally the organization's Corporate Social Responsibility (CSR). In the paper the specific practice of the company, focusing the complexity of new issues is described.

Keywords: Intercultural, HR, CSR, disability, best practic, complex

Disciplines: Economy

A fogyatékosság megítélése relatív, általában a „normális”- hoz történő viszonyításon alapszik. Kurucz és Kemény (2015) azt is megállapítja, hogy a határt normalitás és fogyatékosság között általában a nem-fogyatékos emberek képviselöi jelölik ki (Kurucz, Kemény, 2015). A fogyatékos személyek létszáma Magyarországon 2011-es népszámlálás alapján 457 ezer fö, a népesség 4,6\% -a. Minden ötödik munkaképes korú személy valamely tartósan fennálló egészségügyi probléma, vagy egyéb korlátozottság miatt veszélyeztetett (KSH 2012). Az ilyen személyek, a család és szükebb környezet nem képesek önállóan megoldani a sikeres integrációt, sőt az állami beavatkozás sem elégséges. Szükség van a széles körü társadalmi együttmüködésre.

A vállalatok felelősségvállalásának szükségessége megkérdőjelezhetetlen (Kun, 2010). Ezt a vállalati társadalmi felelősségvállalást az Európai Unió a müködés társadalomra gyakorolt hatásaiért vállalt felelősségként definiálja (Sperkens, 2017).

A vállalati társadalmi felelösségvállalás nagy része törvényi szabályozáson kívül esik, az egyes vállalatok gyakorlatát ennél fogva nem a jogszabályok, hanem sokkal inkább a mások által közzétett jó gyakorlatok inspirálják. Az interkulturális vállalatok híd szerepét betöltve alkalmazhatják a különböző kultúrákban (leányvállalataikhoz, telephelyeikhez kötődve) sikerrel alkalmazott gyakorlatukat további helyszíneken.

Jelen tanulmány újszerüségét az adja, hogy ezen CSR területeket írja le egy vállalat gyakorlatának lehetőségek szerinti legteljesebb feltárásán keresztül. Bemutat olyan jó gyakorlatokat, amelyek inspirálhatnak másokat, döntéshozókat és szakembereket saját jó gyakorlatok kialakítására. Olyan keretrendszert is alkalmaz (tevékenységleltár), aminek segítségével meglévő, vagy tervezett tevékenységeket rendszerezhetnek.

A tanulmány első alfejezete a CSR egy haladó koncepcióját járja körül az elköteleződés kötelezettségek mentén. Ezt követően kerül sor a fogyatékos személyekkel és megváltozott munkaképességüekkel kapcsolatos bánásmód néhány aspektusának bemutatására. A Tanulmány második részében a kutatást és annak eredményeit tárjuk fel. Azt kívánjuk bemutatni, hogy milyen konkrét elemei lehetnek a társadalmi felelősségvállalásnak az egyszerü támogatástól a foglalkoztatáson (ami sajnálatos módon a legcsekélyebb súllyal érhető tetten), az összetettebb programokig.

\section{A vállalati társadalmi felelősségvállalás (CSR)}

A vállalati társadalmi felelősségvállalás (CSR, Corporate Social Responsivility) meghatározására évtizedek óta sokan vállalkoznak a nemzetközi és egyre többen a hazai szakirodalomban is, mi több, definíciókat összegző tanulmányok is napvilágot látnak (Dahlsrud, 2008; Csapóné, 2016). Azt, hogy a felelősségvállalást integrálni kell a vállalati müködésbe 1984-ben Peter Drucker, a menedzsment elméletek atyja úgy fogalmazta meg, hogy a társadalmi problémák kezelését gazdasági lehetőséggé kell formálni (Drucker, 1984).

A felelősségvállalás melletti elköteleződés üzleti szempontból is jelentős megtérülést hozhat (Rayner, 2003). A megtérülés több szinten értelmezhető, mert nem csak a gazdasági 
megtérülés jelenthet hasznot a vállalatok számára, hanem a társadalmi elfogadottság és a társadalmi értékek létrehozása is. Az etikus viselkedés és a gazdasági fejlődéshez való hozzájárulás iránti elköteleződéssel párhuzamosan az ilyen vállalat javítja munkavállalóinak és családjaiknak életminőségét, csakúgy, mint a helyi közösségét és általában a társadalomét (Watts, Holme, 1998).

A kötelezettségek és elvárások irányából megközelítve a CSR „a vállalat oly módon való müködtetése, amely megfelel a vállalatokkal szemben a társadalom által támasztott etikai, jogi, üzleti és társadalmi elvárásoknak vagy túlteljesíti azokat” („Business for Social Responsibility" szervezetet idézi Perrini, 2006, 307.). Általánosan, az érintettek oldaláról tekintve, a vállalati társadalmi felelősségvállalás a vállalatok kötelezettsége, hogy müködése során kielégítse az érintettjei igényeit (Waddock, és tsai, 2002).

Az Európai Unió új, EU CSR 3.0 meghatározásának folyamata jelenleg is zajlik. Ennek fókuszában a közös értékteremtés áll. További kulcsfogalmai: átláthatóság, befogadás, és a foglalkoztatás (Sperkens, 2017).

A CSR stratégiák kategorizálására már az 1970-es években születtek modellek. McAdams (1973) és Wilson (1975) modelljeiben is a vállalat CSR-hez kapcsolódó attitüdje egy kontinuum mentén helyezhető el. Az utóbbiban a CSR stratégiai gondolkodás legmagasabb szintjét a proaktivitás (proactive) jellemzi. Ez a szint McAdams 4 lépcsős evolúciós modelljében a 4. „vezető szerep”-ként definiálható (Become leader in the field), ekkor a vállalat túllépve a minimális elvárásokon vezető CSR szerepre vállalkozik ( McAdams (1973) és Wilson (1975) idézi Barabel, és tsai 2010. 195.o.).

Az 1990-es évektől a CSR-ról szóló viták középpontjában is az áll, hogy a vállalatoknak át kell alakítaniuk szemléletüket a megfelelés szintjéről az elkötelezettség irányába, a károk minimalizálásából az értékteremtés felé (Luetkenhorst, 2004; Novak, 1996).

Ásványi (2014) a vállalatokat (eredetileg adományozási motivációik alapján) tipizálva írja le a haszonszerzési és a külső-belső motivációk dimenzióiban (1.ábra). Ebben a modellben az elkötelezett vállalat célja a felelősségvállaláson keresztül nem elsősorban üzleti haszonszerzés, sokkal inkább a társadalom érdekeit veszi figyelembe. Tevékenységeik hátterében felelősségtudat áll (Ásványi, 2014). A felelősségtudat és elkötelezettség bázisán létre jöhet az értékteremtés.

A közös értékteremtés jelentőségét tárgyalja Csapóné is egy 2016-os vállalati esettanulmányában. A munkatársak, mint a vállalat stratégiai erőforrása, a serkentő szervezeti kultúra, a jó gyakorlatok megosztása biztosíthatják a hosszútávú folyamatos és közös értékteremtést (Csapóné, 2016).

A CSR tevékenységek célcsoportja lehet a szervezeten belül (munkavállalók), és a szervezeten kívül (helyi közösségek, szükebb környezet, tágabb környezet), vagy történhet egy általános társadalmi „közjó”(emberiség, a Föld, példamutatás) érdekében (Bene, 2016).

A vállalatok jelentős része időszakos jelentésekben teszi közzé CSR tevékenységét.

2015-ben az ENSZ Fenntartható Fejlődési Csúcstalálkozón új globális fejlődési programot fogadtak el fenntarthatósági célrendszer kidolgozásával. Ez elsősorban egy általános, nemzeteken túlmutató célrendszer, a továbbiakban régiós, és országos szinten is értelmezhető célokkal és feladatokkal (Faragó, 2015). A 17 Fenntarthatósági cél (Sustainable Development Goals, SDG-s) rendszerét (1. számú függelék) nemzetközi és hazai nagyvállalatok is elkezdték orientációs bázisként használni Fenntarthatósági Jelentéseikben (pl. Bosch, Lexon, Vodafone, Magyar Telekom). 
1 ábra: Vállalatok típusai az adományozások mozgatórugói alapján

(forrás: Ásványi, 2014, 39. o.)

Van haszonszerzési cél

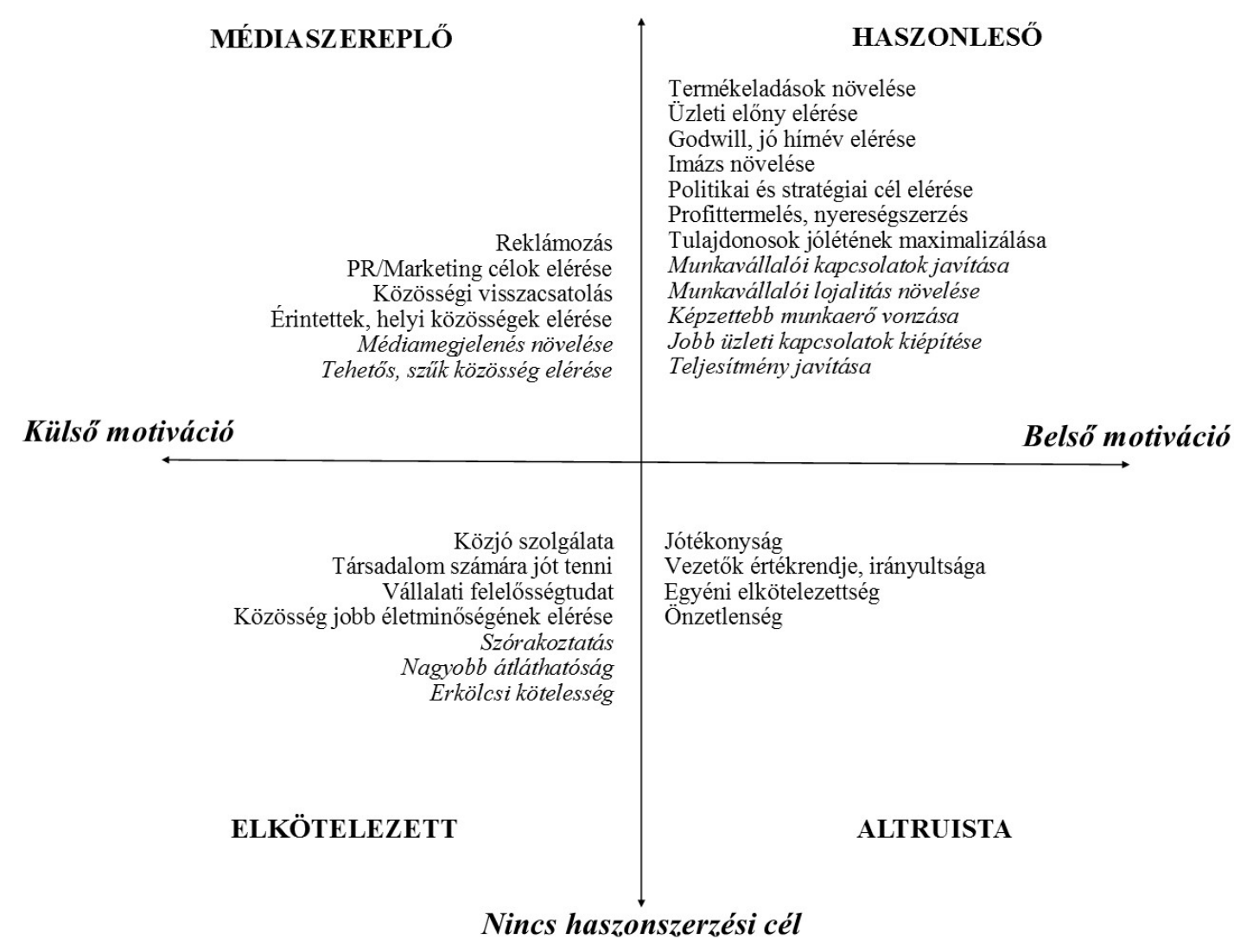

Jelen tanulmány a vállalat társadalmi felelősségének szükebb területére fókuszál, ami a fogyatékos személyekkel, megváltozott munkaképességüekkel való bánásmóddal kapcsolatos tevékenységeket öleli fel.

\section{Fogyatékossággal élők, megváltozott munkaképességúek és a vállalatok}

A fogyatékos személyekkel kapcsolatos legmagasabb szintü jogszabály a Fogyatékossággal élő személyek jogairól szóló egyezmény és az ahhoz kapcsolódó Fakultatív Jegyzőkönyv kihirdetéséről szóló 2007. évi XCII. törvényben foglaltak szerint: „Fogyatékossággal élő személy minden olyan személy, aki hosszan tartó fizikai, értelmi, szellemi vagy érzékszervi károsodással él, amely számos egyéb akadállyal együtt korlátozhatja az adott személy teljes, hatékony és másokkal egyenlő társadalmi szerepvállalását" (2007. évi XCII. törvény, 1. cikk). Megváltozott munkaképességü személynek az tekinthető, aki testi vagy szellemi fogyatékos, vagy akinek az orvosi rehabilitációt követően munkavállalási és munkahely-megtartási esélyei testi vagy szellemi károsodása miatt csökkennek (Szabó, Kozicz és Ottrok, 2012).

A Munka Méltósága című munkajogi projekt keretében a fogyatékossággal élők foglalkoztatási helyzetét is vizsgálták. Jelentésükben rámutatnak, hogy a hazai jogrendszerben nem létezik egységes definíció a fogyatékos személy meghatározására. A megváltozott munkaképességü személy fogalomkör tág, és több homogén csoportot foglal magában, az 
egyes csoportokon belül is jelentős eltérések lehetnek az egészségkárosodás, illetve a fogyatékosság mértékét illetően. A vizsgálatban résztvevő szervezetek ajánlása, hogy kerüljük a fogyatékkal élő személyek szóhasználatot (Szabó, Kozicz és Ottrok, 2012).

Jelen tanulmány a fogyatékos, fogyatékossággal élő és megváltozott munkaképességü kifejezéseket használja. A megváltozott munkaképességűek köre tágabb, azonban ez a fogalom csak korlátozott körben használatos, elsősorban a szabályozói és beszámolói elvárások területén. A CSR tevékenységek (az alkalmazáson túl) célcsoportja egyértelmüen a fogyatékos személyek és a hozzájuk kapcsolódó intézmények, programok, projektek köre.

A megváltozott munkaképességüek munkaerő-piaci lehetőségei összességében erősen behatároltak, tíz érintettböl mindössze kettő dolgozik. Százezres nagyságrendüre becsülik azon érintettek számát, akik célirányos intézkedésekkel, pl. atipikus foglalkoztatási formák elterjesztésével, a közlekedés megszervezésével, munkaállomás kialakításával foglalkoztathatók lennének (KSH 2012). Új munkavállalási lehetőségek feltárására van szükség, újszerü, rugalmas foglalkoztatási formák alkalmazásával lehet elősegíteni a megváltozott munkaképességü emberek munkaerő-piacra való beilleszkedését (Kun, 2010).

A morális akadálymentesítés (Kálmán és Könczei, 2002) az első legfontosabb lépés, abban a folyamatban, amelynek egyik állomása a megfelelő pozíció felkínálása egy megváltozott munkaképességü, vagy fogyatékos személynek. A vezetésnek a kommunikációs munkatársaknak és a humánerőforrás (HR) részleg dolgozóinak kulcsszerepe van a szemléletformálásban. A fogyatékos munkavállalók alkalmazása nem csak az alkalmazott személyre és szükebb környezetére van hatással, hanem az alkalmazó vállalatra, annak megítélésére és áttételesen az egész munkaerőpiacra (Kun, 2010, Kemény, 2015).

Abban a vállalatok és a témával foglalkozó szakemberek is egyetértenek, hogy a meglévő munkatársakat fel kell készíteni a fogyatékos vagy megváltozott munkaképességü kolléga fogadására. Ennek a felkészítésnek a célja az elfogadó, befogadó szemlélet kialakítása, elősegítése. A szakemberképzés, érzékenyítő tréningek biztosíthatják a megfelelő szakmai hozzáértést, és főként az utóbbi a szemléletformálást (Dajnoki, 2014). Szintén lényeges az információ - áramlás elősegítése, a jó gyakorlatok megosztásával. Ilyen jó gyakorlat lehet egy beillesztési program, egy mentor program (Csukonyi, és tsai 2007, Kun, 2010, Móré , 2012).

A jó gyakorlatok megosztásában szintén fontos szerepet kapnak a HR szakemberek. Fórumai lehetnek a különböző HR szakmai találkozók, internetes szakmai oldalak, ahol gyakran különböző szervezetek HR vezetői adnak tanácsot, és osztják meg tapasztalataikat más kollégákkal (Móré, 2012).

A jó gyakorlatokra felhívhatja a figyelmet például egy védjegy. A Fogyatékosság - barát munkahely védjegyet brit mintára vezették be (2. ábra).

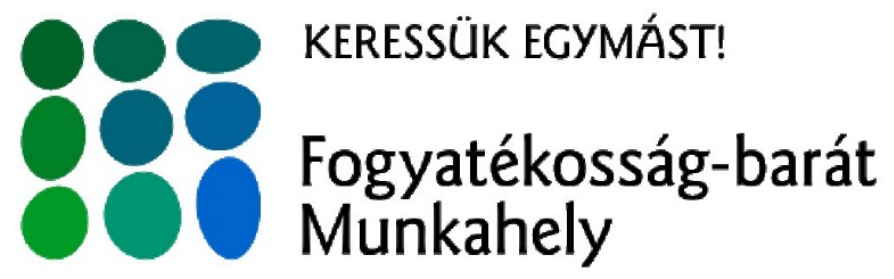


Minden évben az Emberi Erőforrások Minisztériuma, az American Chamber of Commerce in Hungary, a Szövetség a Kiválóságért Közhasznú Egyesület és a bevezető Salva Vita Alapítvány adja át a pályázati feltételeket teljesítő munkáltatóknak . A Fogyatékosság-barát Munkahely logó, - mint védjegy használatát elnyerő munkáltatóknak az Európai Minőségmenedzsment Alapítvány (EFQM) Kiválóság Modellje alapján kidolgozott koncepciónak kell megfelelniük (2.ábra).A díjat azon szervezetek nyerhetik el, amelyek vállalják, hogy folyamatosan fejlesztik a fogyatékos munkavállalók toborzásával, foglalkoztatásával, megtartásával kapcsolatos gyakorlatukat. A nyertes pályázó az elismerés megszerzését követően két évig használhatja a Fogyatékosságbarát Munkahely logót (Net5).

A gazdasági megfontolások mellett (Roberts és tsai 2004; Fedor, Münnich és Sipos, 2007; Dajnoki, 2014; Net9), a vállalati társadalmi felelősségvállalással összefüggésbe hozható fogalmakat, mint a vállalati arculatot, a szervezeti kultúrát, vállalati filozófiát, a vállalati értékeket tekinti számottevőnek a szakirodalom (Roberts és tsai 2004; Kun 2010; Bene 2016) elsősorban a fogyatékosok és megváltozott munkaképességüek alkalmazásának területén.

Ha az alkalmazáson kívül eső (nem ritka, hogy ezek végül alkalmazáshoz vezetnek) fogyatékosokkal és megváltozott munkaképességüekkel kapcsolatos tevékenységeket szeretnénk számba venni, nem áll olyan széles körü szakirodalmi bázis rendelkezésre. Főként esettanulmányok formájában, jó gyakorlatok bemutatásával lehet találkozni (Althoff, 2007; Bene, 2016).

A tematikus napok, vállalati rendezvények, a különböző munkavállalói csoportok vagy ügyfelek, partnerek, esetleg beszállítók számára szervezett képzések hozzájárulhatnak a befogadó kultúra kialakításához (Tardos, 2015). Az ilyen alkalmakat használhatják fel arra a munkáltatók, hogy felmérjék a célcsoporttal szembeni attitüdöket munkavállalóik körében. Gyakori, hogy fogyatékos vendégeket hívnak meg, bevonva öket a tematikus nap történéseibe. Megjelenhetnek meghívott résztvevőként, termékeiket, alkotásaikat kínáló eladóként, fellépőként prózai, zenés, vagy táncos müsorral. Beszámolhatnak élethelyzeteikről, sikereikröl (pl. paralimpikonok), vagy létrehozhatnak közös munkával értéket a dolgozókkal például egy mühelymunka (workshop) keretében (Bene, 2016).

Segítő vásárlásról akkor beszélünk, ha fogyatékos, megváltozott munkaképességü emberek által készített terméket vásárolunk, vagy szolgáltatás értékesítéséhez járulunk hozzá, vagy azt vásárolunk (3.ábra).

\section{1. ábra: Segitő vásárlás védjegy (forrás: Net6)}

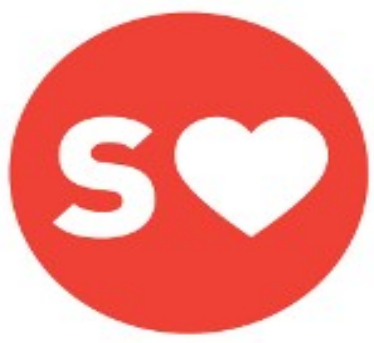

Ez történhet szervezett formában a vállalatok telephelyein, más érzékenyítő programokkal összekötve. Szolgáltatások esetében szintén történhet a vásárlás a vállalat telephelyén, de 
gyakrabban a szolgáltatóhoz inkább kapcsolódó helyszínen, egy szállodai komplexumban, egy étteremben. Ilyen vállalkozás a Hotel Panda Budapesten (Net7), a Hatpöttyös étterem Székesfehérváron (Net8), vagy a Neo Interactive digitális reklámügynökség (Net9). A Kockacsoki csokoládémanufaktúra az édességek mellett táborokat, tanfolyamokat kínál (Net10). A Segítő Vásárlás nevet viselő programot az Emberi Erőforrások Minisztériuma 2010-ben indította el annak érdekében, hogy felhívja a figyelmet a fogyatékossággal élő emberek közremüködésével készített termékekre és szolgáltatásokra. 2013-ban védjegyet jegyeztek be a programhoz (Net6).

A védjegyet a megváltozott munkaképességü embereket foglalkoztató akkreditált, védett munkáltatók használhatják termékeiken, tanúsítva, hogy ezek a termékek megváltozott munkaképességüek közremüködésével készültek. Egy design projekt is elindult 2014. júniusától azzal a célkitüzéssel, hogy a kortárs ízlésnek megfelelö, piacképes termékek készüljenek a fogyatékossággal élőket foglalkoztató mühelyekben formatervezőkkel együttmüködve (Net6).

A para-sport támogatása a sportrendezvények támogatásától a nemzeti válogatottak, szövetségek, csapatok az egyéni sportolók támogatásán át a tömegsport támogatásáig terjed a sporttevékenységen innen és túl. Ugyan a vállaltok a sport szponzorációt elsősorban marketing eszközként használják, de a para-sport támogatásának filozófiai hátterében hangsúlyosan megjelenhet az esélyegyenlőség, a társadalmi integráció serkentése. Mivel a sporttevékenység, a sportfogyasztás fokozott emóciós töltettel jár, különösen alkalmas pozitív üzenetek terjesztésére, szemléletformálás közvetítésére (Althoff, 2007).

Az olyan marketingtevékenység önmagában társadalmi célúnak tekinthetö Donovan és Hanley (2010) szerint, aminek egyik célja lehet, hogy társadalmi jót célzó tudatosságot, pozitív attitüdöt, alakítson ki, illetve ösztönözzön (Donovan, Henley 2010, idézi Balázs, Koncz, 2016. 13.o.). Az esélyegyenlőség, a befogadás és elfogadás ösztönzése társadalmi célúnak tekinthetö.

Jelen tanulmány az alkalmazással és az alkalmazáson túl megvalósuló, fogyatékos személyekkel és megváltozott munkaképességüekkel összefüggő CSR tevékenységek körének rendszerezésére vállalkozik egy nemzetközi nagyvállalat magyar leányvállalatának tevékenységének bemutatásán keresztül, a teljesség igényével a módszertani korlátokat figyelembe véve. Nem tárgyaljuk ennek kormányzati (mint minisztériumi felelösségi körök, díjak, részletesen pl.: 1025/2006.(III.23) Kormányhatározat ) és gazdasági (pl. rehabilitációs hozzájárulás, részletesen: 2011. évi. CXCI. Mmtv.) aspektusait.

\section{Módszer}

Szekunder adatokra alapozott másodelemzést valósítottunk meg.

A kutatásban alkalmazott kevert módszertan kiválasztásakor figyelembe vettük azt a kutatásmódszertanban pragmatista hozzáállást, miszerint a társadalmi jelenségek vizsgálatánál a hangsúly a módszertanról és a kutatási eljárásról áttevődik a vizsgálandó problémára. A probléma megértéséhez, feldolgozásához minden rendelkezésre álló elméleti felfogást és módszertani keretet fel lehet használni (Creswell, 2009). Géring (2017) hiánypótló módszertani tanulmányában részletesen bemutatja, hogyan lehet szövegelemző módszerekkel vállalati társadalmi felelősségvállalást, mint társadalmi jelenséget, honlapok elemzésével megvalósítani. A szerző szintén ebben az írásban részletezi, a kevert módszertan, azaz a kvantitatív tartalomelemzés, és egy kvalitatívabb fókuszú diskurzuselemzési eljárás alkalmazásának előnyeit. Nem csupán egyes szavak, hanem általánosabb témák, programok és kezdeményezések megjelenését is vizsgáltuk. Ezért azt is mondhatjuk, hogy a webtartalomelemzés Herring (2009) által bemutatott különbözö kutatási területei közül ez a kutatás a szövegek (vállalati honlap) témastruktúrájának feltárására is irányult, de nem terjedt 
ki az imázselemzésre, a linkelemzésre, a szövegjellemzők, vagy a szövegek közötti hivatkozási rendszerek elemzésére.

Az elemzési egység a teljes vállalati honlap volt, melynek elemzése során a honlapszövegeket és a letölthetö anyagokat (pl. jelentések, sajtóközlemények) egyaránt figyelembe vettük. Jelen vizsgálat során az elemzési egység részét képezték a nem magyar nyelvü tartalmak is, de azzal a kikötéssel, hogy a magyar leányvállalat tevékenységéhez kapcsolódjanak.

A kialakított vizsgálati szempontrendszer 4 fókusz köré rendeződik:

1. a vállalati kommunikációban megemlített érintetti csoportok feltárása,

2. a vállalati felelősségvállalás fogyatékossággal élőkhöz, megváltozott munkaképességüekhez bármely módon kapcsolódó különböző témáinak, területeinek megjelenése, időbeli változása a vizsgált időszakban,

3. a különböző vállalati programok megjelenése (tevékenységleltár elemei),

4. összetett programok, amik érintenek fogyatékossággal élő vagy/és megváltozott munkaképességü személyeket.

Az alkalmazott tartalomelemzés és diskurzuselemzés a hozzáférhetőséget prioritásként kezelve kiterjedt:

- a magyarországi vállalati honlapra (Net1),

- a német anyavállalat honlapjára (Net2).

A honlapok vállalati társadalmi felelősségvállaláshoz kapcsolódó felületei változó mértékben naprakészek, indokolt volt külön figyelmet fordítani a honlapon elérhető 2016-os és 2017-es hírfolyamokra és a kapcsolódó letölthető releváns sajtóközlemények elemzésére. Ezek:

- Éves jelentés 2016.,

- Fenntarthatósági Jelentés 2014.,

- Fenntarthatósági Jelentés 2015.,

- Fenntarthatósági Jelentés 2016,.

- A Vállalat esélyegyenlőségi terve a 2016. január 1-től 2020. december 31-ig terjedő időszakra

- Egyéb internetes tartalmak (pl. youtube) voltak.

Az eredmények strukturálásának vezérfonalát Bene (2016) tevékenységleltár rendszere határozta meg. A struktúra segítséget nyújtott a tevékenységek szisztematikus bemutatására.

\section{A vállalat gyakorlata - CSR tevékenységek a fogyatékos személyekkel és megváltozott munkaképességüekkel kapcsolatba hozható területeken}

Az alábbiakban egy multinacionális nagyvállalat magyar leányvállalatának azon tevékenységeit tárjuk fel, amelyek fogyatékosokkal, megváltozott munkaképességüekkel való bánásmódhoz köthetők. A vizsgálat elsősorban a közelmúlt és jelenlegi tevékenységeire fókuszál.

A vizsgálat vállalat Magyarország legnagyobb távközlési szolgáltatója. Telekommunikációs és infokommunikációs (ICT) szolgáltatásokat nyújt vezetékes és mobil viszonylatban, adatátviteli és nem hangalapú, informatikai és rendszerintegrációs területeken. A vállalat egy német anyavállalat magyar leányvállalata. 
- Jövőképük: „Elsők vagyunk és elsők is maradunk.”(Net1)

- Küldetésük: „Érthetőbbé és elérhetőbbé tesszük a digitális világot. Mindenkinek biztosítjuk a könnyebb, színesebb és sikeresebb élet lehetőségét.”(Net1)

2016. december 31-ével az alkalmazottak átlagos statisztikai állományi létszáma: 6221 fó volt. Az egész vállalatcsoportot érintő 2014-ben bejelentett 1000 föt meghaladó létszámleépítés 2016-ra is elhúzódott.

A Vállalat legutóbbi, 2016-os Fenntarthatósági Jelentésében csakúgy, mint korábban, külön fejezetben rendszerezi az érintettekhez kapcsolódó tevékenységét társadalmi felelősségvállalásának jegyében.

A vállalat érdekelt feleinek (stakeholder) körébe azok a csoportok tartoznak, amelyek hatással vannak céljainak megvalósítására, vagy érdekeltek abban (4. ábra). „Irányítási rendszereinek és benchmarkvizsgálatainak áttekintésével azonosította az érdekeltek körét, és állandó kapcsolatot tart velük, hogy érdekeiket müködése során figyelembe vegye" (Vállalat Fenntarthatósági Jelentés 2016., 10. o.).

\section{4. ábra: A vállalat érdekelt felei}

forrás: saját szerkesztés a Vállalat Fenntarthatósági Jelentés 2016., 10. o. alapján

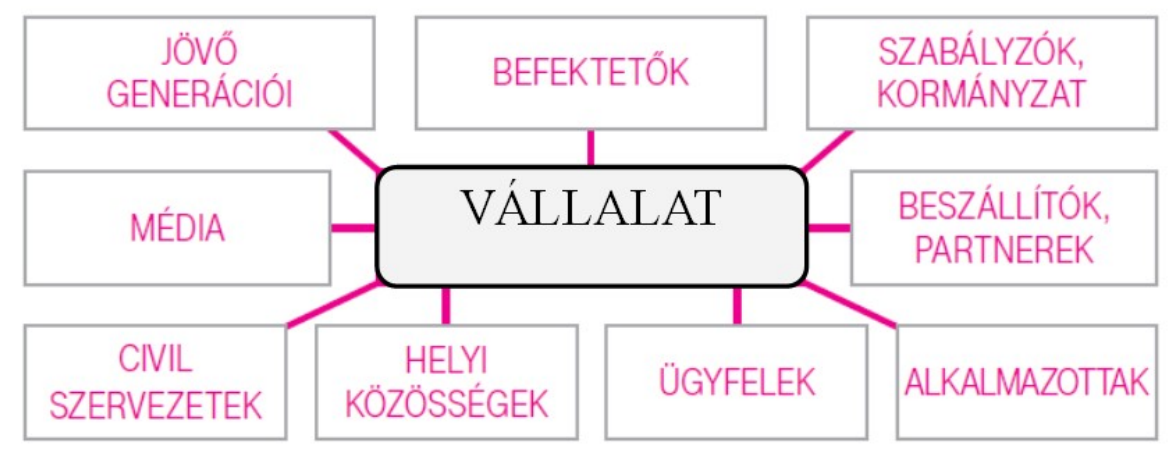

A Fenntarthatósági jelentéshez kapcsolódva évente végeznek kérdőíves kutatást stakeholdereik körében a fenntarthatósági témák fontosságát illetően. Arra kérik a kitöltőket, hogy számszerüsítsék a vállalat fenntarthatósági teljesítményének megítélésére gondolva egy 5 fokú Likert skálán mennyire tartják fontosnak az egyes témaköröket.

A fogyatékossággal élőkkel és megváltozott munkaképességüekkel kapcsolatba hozható CSR tevékenységek az alábbi témákban érhetők tetten ebben az értékelésben:

A. Emberi jogok, esélyegyenlőség

B. Munkahelyi egészség és biztonság

C. Munkatársaink a társadalmi felelősségvállalásban

D. Adományozás

E. Beszállítóink elismerése pl. Delfin díj (korábban Delfin díj a felelős vállalatoknak)

Az utóbbi években egységesen a legmagasabb átlag pontszámokat az emberi jogok, esélyegyenlőség (A), és a munkahelyi egészség és biztonság (B) kapták (adattábla a 2. sz. függelékben). 
A 2016-os Fenntarthatósági Jelentésben fenntarthatósági témáik lényegességi besorolását közlik. Jelen tanulmány szempontjából releváns témák és lényegességük ebben a rendszerben:

- Magas prioritású témák: Munkatársak bevonása; Digitális felzárkóztatás; Ügyfél elégedettség; Emberi jogok, esélyegyenlőség

- Közepes prioritású témák: Munkatársaik a társadalmi felelősségvállalásban; Ügyfélpanaszok kezelése; Ügyfeleik bevonása; Biztonságos mobilhasználat, elektromágneses terek; Delfin Díj a felelős vállalatoknak

- Alacsony prioritású témák: Munkahelyi egészség és biztonság; Ügyfeleik tájékoztatása; Szponzorálás;

A vállalat kedvezményes díjcsomagot kínál az érintett érdekvédelmi szervezetek tagjainak, amelyek: MEOSZ (Mozgáskorlátozottak Egyesületeinek Országos Szövetsége), MVGYOSZ (Magyar Vakok és Gyengénlátók Országos Szövetsége), ÉFOÉSZ (Értelmi Fogyatékossággal Élők és Segítőik Országos Érdekvédelmi Szövetsége).

A honlapok és hírfolyamok elemzése alapján összeállítható egy széles spektrumú tevékenység rendszer. A Függelék 3. ábrája egy korábbi tanulmány (Bene 2016) alapján összefoglalja a vállalati társadalmi felelősségvállalás azon tevékenységeit, amelyek fogyatékossággal élőkkel és a megváltozott munkaképességüekkel való bánásmódhoz köthetőek. Ezen struktúrát használva vezérfonalként a vállalat belső (vállalaton belüli) és külső ilyen tevékenységeit foglaljuk össze a következőkben.

\section{Alkalmazás}

A vállalat - monitoring által elismerten - teljesítette a 2013-ban elnyert Fogyatékosság barát Munkahely címre beadott pályázatában tett kétéves vállalásait. A Fogyatékos Emberek Világnapján megrendezett „Jobb velünk a világ!” gálaesten osztották ki a 2015. évi Fogyatékosság-barát Munkahely díjakat. A cím elnyerésével újabb két évre jogosulttá váltak a „Fogyatékosság-barát Munkahely ” logó használatára.

Az atipikus foglalkoztatási formák egyre szélesebb alkalmazásával a fogyatékossággal élök (elsősorban mozgásukban korlátozottak) és megváltozott munkaképességü dolgozók speciálisabb igényeinek való megfelelés mellett azt is támogatja vállalat, hogy a családosok egyenlő eséllyel állhassanak helyt munkavállalóként és szülőként, nagyszülőként is. Stratégiailag is fontos a vállalat számára, hogy a vállalati kultúra részévé váljon a távmunka, ehhez számos, a napi müködésbe épített gyakorlat, illetve a távmunkavégzést speciálisan támogató nagy légterű iroda, a „Future Work” is hozzájárul. A 2012 óta havi rendszerességgel meghirdetett „Dolgozz otthonról!” felhívás nyomán folyamatosan növekszik az adott napon távoli hozzáféréssel munkát végzők létszáma. 2017. június elsején indult a „Távmunka a Vállalatnál. Te is változtatnál a világon? Tedd velünk!” kampány reklámfilmekkel, távmunkában dolgozó egy-egy kolléga napját elmesélve.

\section{Akadálymentesités}

2016 májusára újult meg a vállalat honlapja. A nem látók és gyengén látók igényeit szem előtt tartva a vállalati portálon több száz oldal könnyebben használható felolvasószoftverrel is. $\mathrm{Az}$ eÁSZF (elektronikus Általános Szerződési Feltételek dokumentum) akadálymentes üzemmódban is elérhetővé vált 2016 végére.

A IX. Fenntarthatósági Napon 2016. szeptember 24-én, az akadálymentesítés, és az esélyegyenlőség, jegyében is jelentek meg kiállítók. Az egyik szekcióbeszélgetés témája a Smart-eszközök szerepe az akadálymentesítés területén-volt. Díjat nyert (közönségszavazat 3. hely) a mozgássérültek sportolását segítő Suhanj! Alapítvány. 


\section{Egészségmegörzés}

A vállalat munkahelyi egészségvédelmi és munkabiztonsági politikájában stratégiájával összhangban egészségterv kidolgozása és müködtetése, egészségmegőrző és megelőző programokat szervezése mellett kötelezte el magát.

2015-ben is megszervezte a hagyományos „Egészséghét” programját a munkavállalók egészségének megőrzéséért. A 2015. évi program mottója: „1 hét kiemelt figyelem az egészségre, fókuszáltabb figyelem a stressz kezelésére" volt. Ennek keretében stresszszürések, lelkiegészség-programok, előadások, tréningek, pszichológus részvételével egyéni konzultációk során volt lehetőség tájékozódni a témában vagy segítséget kérni igény esetén. Komplex stresszfaktorszürésre (online stresszteszt, valamint müszeres orvosi és laboratóriumi vizsgálatok elvégzésére) 6 budapesti és 5 vidéki helyszínen került sor. Az online stresszkérdőívet 1076 munkatárs töltötte ki, orvosi és laborvizsgálaton 708 fö vett részt. 2016ban már 8 város 18 helyszínén zajlott a program egy hónapos „Egészséghetek” néven „Okosan élünk, okosan dolgozunk” mottóval.

A vállalat 20 éve a Vivicittá Városvédő Futás névadó szponzora. A futóversenyhez belső és külső kampányok kapcsolódnak. Egyik, a tömegsportrendezvényhez kapcsolódó projektjük keretében a Suhanj Alapítvánnyal közösen teszik lehetővé a részvételt fogyatékos személyeknek önállóan, speciális segédeszközzel, vagy ép kísérővel.

\section{Belsö kampány, akció}

A vállalat és a Fenntarthatósági Média Klub (FMK) tagjai Adni Jó! Sütiakció néven jótékonysági sütemény-vásárt rendeztek az Önkéntesség Világnapján, 2016. december 5-én. Ennek keretében a vállalat önkéntes dolgozói és az FMK tagjai saját készítésü süteményeiket kínálták eladásra országszerte 15 helyszínen, a vállalat telephelyein. A süteménykért felajánlott, a becsületkasszába befolyt bevételt jótékony célra ajánlják fel, így idén az Autistic Art Alapítvány múvészetterápiás programját támogatják vele.

\section{Etikai kódex, formalizált esélyegyenlöség}

A Csoport Szociális Chartája, valamint a mindenkor hatályos Esélyegyenlöségi terve rögzíti a vállalatcsoport általános emberi jogi alapelveit.

Létezik a vállalatnál egy a belső ellenőrzésekre vonatkozó etikai kódex is.

A vállalat egyike volt azon magyar vállalatoknak, amelyek csatlakozásukkal deklarálták a sokszínüség, mint alapérték melletti elkötelezettségüket 2016-ban, amikor Magyarország is csatlakozott az Európai Sokszínüségi Kartához.

\section{Segítő vásárlás}

A vállalat megújítja az üzleteiben dolgozó értékesítő munkatársak formaruháját. Az új formaruha egyik fontos tartozéka egy olyan hernyóselyem kendő, amelyre az Autistic Art Alapítvány müvészeti programja keretében alkotó autista fiatalok rajzai kerültek. Az első közel 100 darab ilyen sálat Gyenes András, a vállalat lakossági szolgáltatások vezérigazgatóhelyettese és Bella az Alapítvány ügyvezetője adta át a vállalat üzletvezetőinek Kecskeméten 2016. szeptember 29-én.

Az Autistic Art dizájnmárka a fiatalok müvészeti foglalkozásokon készítettek rajzaikra épül, amelyekből designerek bevonásával készítenek magas münőségü termékeket. A márka célja egyrészről a forrásteremtés, másrészről az, hogy megmutassa autista fiatalok közremüködésével is készülhetnek minőségi tárgyak, tehát ők is hasznos tagjai lehetnek a társadalomnak. Az Autistic Art termékek eladásából az Alapítvány 16 évesnél idősebb autisták számára létrehozott 11 bentlakásos otthon müködését támogatja, ahol több mint 200 fiatalt látnak el. 


\section{Pénzbeli támogatás intézménynek, szervezetnek}

A vállalat a sütemény-vásár mellett további lehetőségeket kínál azoknak, akik csatlakozni szeretnének a jótékony célú adományozáshoz, és szívesen támogatnák az autista fiatalok művészetterápiás programját. Egy foodstylist és ételfotós páros fotókat készített a sütemények felhasználásával a vállalat budapesti Krisztina Körúti Székházába, amelyekből elektronikus formájú képeslapok lettek. Ezeket a képeslapokat bárki elküldhette szeretteinek, vagy üzleti partnereinek a vállalat tematikus karácsonyi honlapján keresztül 2016. december 14-24. között. A vállalat minden képeslap elküldése után 100 forintot adományozott az Autistic Art Alapítványnak. A kampányba az Instagram-os megosztásokat is bekapcsolták.

A hello holnap! applikáción keresztül az adományozási időszakokban a felhasználók pontokat gyüjthetnek, amiket forintra váltva adományozhatnak a megjelölt civil szervezeteknek. A rendszer a 2014-es fenntarthatósági Napon debütált. 2017 első adományozási időszakában a 9 szervezet közül 3 fogyatékkossággal élőket támogató szervezet. Ezek, az autizmussal élőket támogató Autistic Art, az Artman Mozgásterápiás Művészeti Közhasznú Egyesület, ami azzal a céllal alakult, hogy oktatási, müvészeti és terápiás programok létrehozásával segítse a különböző fogyatékossággal élő emberek társadalmi felzárkóztatását és a Suhanj! Alapítvány amely 2010 óta osztja meg a mozgás örömét sérült és fogyatékkal élő személyekkel.

\section{Pénzbeli támogatás magánszemélynek}

A vállalat támogatja Adámi Zsanett paralimpikon úszót. A 2016-os riói nyári paralimpia ideje alatt üzemeltette az egyekvagyunk.hu oldalát, amely segítségével 2016. szeptember 7 és 18-a között szívdobbanást küldhettek az ügyfelek, vagy üzenetet a parasportolóknak is Rióba. A szív alakú okoseszköz Adámi Zsanett paraúszónál jelezte a szurkolók biztatását.

\section{Program támogatása}

A vállalat a magyar sport elkötelezett partnereként és a magyar olimpiai csapat platina fokozatú támogatójaként fontosnak tartja, hogy támogassa a hazai paralimpikonokat is, és hozzájáruljon a parasport hazai ismertségének és népszerüségének növeléséhez. Ezért a vállalat együttmüködésről szóló szándéknyilatkozatot írt alá 2016. augusztus 31-én a Magyar Paralimpiai Bizottsággal, amely értelmében a vállalat a következő paralimpiai ciklusban segíti a hazai csapat felkészülését.

\section{Időadomány}

A vállalat önkéntes napot szervezett 2016. október 15-én. Az országos megmozduláson a vállalatcsoport több mint 1000 munkatársa és családtagjaik vettek részt, akiknek köszönhetően 29 helyszín, köztük számos vállalati telephely és közterület, illetve óvodák, iskolák, szociális intézmények, fogyatékossággal élők lakóotthonainak környezete újult és szépült meg. Az esemény keretében elsősorban fákat és bokrokat ültettek a vállalatcsoport munkatársai, de emellett végeztek környezetrendezési, valamint karbantartási munkálatokat is. Így a nap végére több mint 1000 fával és cserjével gyarapodott az ország és a hello holnap! pagony névre keresztelt virtuális erdő, ahova az azonos nevü mobil Facebook applikáció segítségével bárki feltöltheti ország bármely pontján a saját maga által ültetett fát, fákat. Szegeden a Gemma Szociális Szolgáltató Központ és Fejlesztő Iskola területén kertet rendeztek, kerítést bontottak és padokat festettek a vállalat önkéntesei. Miskolcon két helyszínen is dolgoztak, fákat ültettek a Szimbiózis Alapítvány lakóotthonának, továbbá az Autistic Art Alapítvány által támogatott Miskolci Autista Alapítvány Szakáld községben lévő lakóotthonának területén is. 
Kérés, egyedi adomány

A Hallás Társasága Alapítvány kezdeményezésére több mint 10 millió forint értékü támogatással segíti egy több vállalatból álló alkalmi mecénás klub a nagyothalló fiatalok felsőoktatásban való eredményes részvételét. Az összefogás eredményeként 2015-ben 5 fiatalt támogattak. Az eszközök internet-hozzáférését a vállalat, a hallókészüléket egy forgalmazó, a készülékeket egy iparvállalat biztosítja.

\section{Beszállitók értékelése}

A Beszállítók értékelését több rendszeren keresztül is megvalósítják (ECOVADIS, MTKérdőív, Audit, Előminősítés, Supplier score card, GESI).

A beszállítókra alkalmazott kockázatértékelési szempontrendszer elemei között megtalálható a beszállítóra vonatkozó: alkalmazotti egészség és biztonság; a diszkrimináció.

A bemutatott tevékenység leltárban külön kategóriaként nem szereplö, azonban abba szervesen beilleszthető további tevékenység terület lehet a fogyatékosságokkal, tágabban értelmezve bármely egészséggel, betegséggel kapcsolatos kutatás, vagy fejlesztés támogatása, komplex, kategóriákon átívelő tevékenységek a stratégiai partnerség, és a díjak, elismerések:

\section{Kutatás fejlesztés támogatása, szemléletformálás}

Az anyavállalat által 2016 májusban indított 'Sea Hero Quest' mobiljáték új távlatokat nyit a demencia kutatásában. A játékot az Alzheimer’s Research intézmény, valamint kutatók és játékfejlesztők együttmüködésével fejlesztették. Eddig több millióan játszották már a 'Sea Hero Quest'-et, amit fontos lépésként értékelnek a demencia új, korai diagnosztizálását célzó eszköz kifejlesztése szempontjából. A Sea Hero Quest a világon mindenhol, kortól és nemtől függetlenül tesztelte az emberek tájékozódási képességét, a kutatócsapat pedig San Diegoban, a Neuroscience 2016 konferencián bemutatta a játékkal begyüjtött adatok elsődleges elemzéséből származó eredményeket.

A 'Sea Hero Quest' játék tükrözi a vállalat világképét, digitális felelősségérzetét valamint innovációs vezető szerepét. "Emberek milliói bocsátottak rendelkezésünkre adatokat, segítve ezzel a demencia elleni küzdelmet. A biztonságos felhőben tárolt, hatalmas mennyiségü adatok révén olyan alapanyagot biztosíthatunk a tudósoknak, amire nagy szükségük van a legkorszerübb kutatások során. A digitalizáció áttörést jelent a közegészségügyi helyzet javításában"- mondta az anyavállalat vezérigazgatója (Net2).

Magyarországon 2016. május 5. és június 30. között futott a kampány, amelynek hatására közel 150 ezren töltötték le a mobiljátékot. Ennek a folyamatnak részeként, a Sea Hero Quest támogathatja a demencia korai felismerését, diagnosztizálását, illetve hatással lehet a demenciás páciensek kezelésére is. A folyamat során a mobiljátékot a páciensek térbeli tájékozódási képességei esetleges javulásának mérésére is fel lehet használni. Felhasználható a kísérleti gyógyszeres kezelések hatékonyságának mérésére is.

A játékra buzdítva 2017 szeptember 21-én jelentette meg a vállalat a youtube közösségi videomegosztó csatornán azt a kisfilmet, amit az első hónapban több mint 50 000-en néztek meg (Net13). A Vasárnap címü rövidfilmet az Alzheimer világnapra készítették azzal a szándékkal, hogy az emberek jobban felfigyeljenek a betegségre és aktívan segítsenek a játékban való részvételükkel. A film végén megjelenő üzenet: „Magyarországon mintegy 250000 ember szenved demenciától, akinek családjára és környezetére is súlyos terheket ró a betegség." A film a vállalati honlapon nem található. 


\section{Stratégiai partnerség}

A vállalat 2016. március 30-án az Autistic Art Alapítvány civil stratégiai partnere lett. A támogatás keretében eszközökkel, önkéntes munkával, kommunikációs felületekkel és szolgáltatások biztosításával segíti a vállalat az alapítvány munkáját. Az Autistic Alapítvány 2010-ben indította el művészeti programját, amelynek keretében lakóotthonokban élő autista fiatal felnőtteknek biztosítanak rendszeres rajzfoglalkozásokat, akik a grafikákon keresztül kommunikálnak a külvilággal és a rajzolás által fejezik ki érzéseiket, gondolataikat, mutatják meg gazdag belső világukat. A több éven át tartó partnerség során a vállalat legfontosabb adománygyüjtő akcióinak kedvezményezettje az Autistic Art - Mosoly Otthon Alapítvány lesz: a 2016-os nagy futórendezvénysorozaton a Vivicittán a vállalat munkatársai valamint a Fenntarthatósági Média Klub tagjai az alapítványért futottak. A vállalat az autizmussal élők számára létrehozott lakóotthonokat, ezáltal az autisták mindennapjait technológiai megoldásokkal, infokommunikációs eszközökkel és szolgáltatásokkal is támogatja, az önkéntesei pedig az otthonok felújításában nyújtanak segítséget. Emellett kommunikációs felületein, a vállalat fesztivál- és sportszponzorációjában, eseményeken, például a Fenntarthatósági Napon, továbbá egyéb formákban is megjelenési lehetőséget biztosít. A hello holnap! applikáción keresztül támogatható egyik szervezet az Autistic Art Alapítvány. 2016 őszén a vállalati székház adott otthon az Alapítvány éves jótékonysági aukciójának. Az aukció keretében a lakóotthonokban élő fiatalok és kortárs müvészek alkotásaira licitálhattak a résztvevők. Az önkéntesség világnapjához kapcsolódó Adni jó! Sütiakció és a karácsonyi jótékony képeslapküldés is az Alapítványt támogatta.

\section{Díjak, elismerések}

2008-ban megalapították a DELFIN Díjat: Díj egy Elkötelezett, Fenntartható, Innovatív Nemzedékért.

A DELFIN Díj odaítélésével a vállalat a fenntartható fejlődés gondolatának népszerüsítését szeretné elősegíteni minden magyarországi vállalat körében, és ezirányú tevékenységüket kívánja elismerni. A díjat a fenntarthatóság terén kiemelkedő szerepet vállalók kaphatják meg, odaítéléséről a beadott pályamunkák alapján szakmai zsüri dönt.

A DELFIN Díjra bármely Magyarországon működő vállalkozás pályázhat már megvalósult projektekkel vagy müködő programokkal. A díjakat (4 kategóriában) az éves Fenntarthatósági kerekasztalbeszélgetéshez kapcsolódva adják át.

Esélyegyenlőség kategóriában 2013 után 2015-ben ismét a JOB Személyzeti Tanácsadó érdemelte ki a díjat, ezúttal a megváltozott munkaképességüek munkaerőpiaci integrációját segítő www.rehabjob.hu portál, Facebook-oldal és blog létrehozásával.

Tudatformálás terén pedig a Hegyvidéki Sportcsarnok és Sportközpont (MOM Sport) társadalmi felelősségvállalási tevékenysége, különösen a halmozottan hátrányos helyzetü sportolóknak rendezett versenyei kapcsán.

2017-ben ugyanezen kategóriában az Alko-soft Szolgáltató Nonprofit Bt. lett díjazott. A cég olvasást segítő eszközök magyarországi forgalmazásával, honosításával, Ingyenes Digitális Könyvtár üzemeltetésével segíti a látássérülteket, emellett kifejlesztette az eRikkancs rendszert, amely lehetővé teszi, hogy a látássérültek a nyomtatott sajtót elektronikusan tudják olvasni számítógépük segítségével.

\section{Összefoglalás}

Jelen tanulmány feltárta egy vállalat társadalmi felelösségvállalásának széles eszköztárát a fogyatékos személyekkel, megváltozott munkaképességüekkel való bánásmód területén a kapcsolódó tevékenységek és jó gyakorlatok felvonultatásával.

A fogyatékos, megváltozott munkaképességü személyekkel, szervezeteikkel kapcsolatos CSR tevékenységek a vállalatoknál a legtöbb esetben szigetszerünek tünnek. Érzékelhető, 
hogy a megváltozott munkaképességüek foglalkoztatásának korlátai vannak, nagyobb arányú foglalkoztatást olyan vállalat tud biztosítani, amely képes megfelelő számú alkalmas munkakört kínálni.

A vizsgált vállalat a tágan értelmezett érintettjeit bevonva valósítja meg a fogyatékossággal élő, a megváltozott munkaképességü munkavállalókkal kapcsolatos CSR tevékenységét.

A jó gyakorlataik között vannak belső, és külső tevékenységek, összetett programok, együttmüködések.

A tanulmány feltárta ezek kapcsolatrendszerét és tartalmát tevékenységleltárat felhasználva vezérfonalként, kevert szövegelemzési módszertant alkalmazva a téma szempontjából releváns dokumentumok és internetes tartalmak esetében.

Bemutatott olyan jó gyakorlatokat, amelyek inspirálhatnak másokat, döntéshozókat és szakembereket saját jó gyakorlatok kialakítására. A vállalat jövőképére hangolva proaktív vezető szerep betöltésére tör a vállalati társadalmi felelősségvállalás jelen tanulmányban vizsgált területein.

Korlátozásként említhető a módszertanból fakadó korlátokon túl az önbevallás szubjektivitása, ami a vállalati társadalmi felelösségvállalás kommunikációjában általánosan jellemző. További vizsgálati módszerek alkalmazása - például interjú vállalati CSR felelős szakemberrel - a témakörök teljesebb kidolgozására adhat lehetőséget. A német anyavállalat hasonló szempontok alapján történő elemzése alkalmat adhat egy szélesebb kitekintésre, további összefüggések, jó gyakorlatok bemutatására.

\section{Irodalom}

Althoff, S. (2007). Das Sportsponsoring der Telekom — und was dahinter steckt In: Althoff S. Exzellentes Sponsoring. Deutscher Universitäts-Verlag, 77-102.

Ásványi, K. (2014). A komolyzenére irányuló CSR vállalati megítélése: Vállalati attitűdvizsgálat Q-módszerrel. Marketing és menedzsment 48:(1), 37-46.

Balázs, K., Koncz, V. (2016). Metaforikus és perspektívaváltást igénylő társadalmi célú reklámok hatásvizsgálata. Alkalmazott Pszichológia, 16(3), 7-34.

Barabel, M., Combes, M., Meier, O., \& Nicolaï, I. (2010). Perception and legitimating of CSR within a multinational firm: the case of the DEXIA Group. Revue internationale de psychosociologie, vol. xvi,(38), 191-208.

Bene, Á. (2016). A CSR különleges bánásmódja Különleges Bánásmód 2016/2, 27-41.

Creswell, J. W. (2009). Research Design. Qualitative, Quantitative and Mixed Methods Approaches. Sage Publications, CA, Thousand Oaks

Csapóné Riskó, T. (2016). Fókuszban az alkalmazottak, Studia Mundi-Economica, 3:(1) 2639.

Csukonyi, Cs., Máth, J., Medvés, D., \& Pántya, J. (2007). Munkahelyi beillesztés a megváltozott munkaképességü személyek munkaerö-piaci integrációjában In Münnich, Á. (szerk.), Gyakorlati megfontolások és kutatási tapasztalatok a megváltozott munkaképességü emberek foglalkoztatásához (25-45o.) Debrecen: Didakt Kkiadó

Dahlsrud, A. (2008). How Corporate Social Responsibility is Defined: an Analysis of 37 Definitions. Corporate Social Responsibility and Environmental Management 15., 113.

Dajnoki, K. (2014). Fogyatékos munkavállalók beillesztésének elösegítése, különös tekintettel az érzékenyítő tréningekre. Taylor, Gazdálkodás- és szervezéstudományi folyóirat VI. évf./1-2. szám No14-15., 157-168. 
Drucker, P. F. (1984). The new meaning of corporate social responsibility. California Management Review, Vol. 26, pp.53-63.

Faragó, T. (2015). A fenntartható fejlődés új ENSZ-programja, file://C:/torrent/SDGsFarag\%C3\%B3Tibor.pdf

Fedor, Gy., Münnich, Á., \& Sipos, S. (2007). A munkaadó szervezetek megváltozott munkaképességü munkavállalók foglalkoztatására való felkészültségének feltáró vizsgálata In Münnich, Á. (szerk.), Gyakorlati megfontolások és kutatási tapasztalatok a megváltozott munkaképességü emberek foglalkoztatásához (25-45 o.) Debrecen: Didakt Kkiadó

Géring, Zs. (2017). Kevert szövegelemzési módszertan alkalmazása gazdasági és társadalmi jelenségek vizsgálatához: Online CSR-kommunikáció vizsgálata tartalomelemzéssel és diskurzuselemzéssel, Vezetéstudomány, 48:(4), 55-66.

Herring, S. C. (2010). Web Content Analysis: Expanding the Paradigm. in: Hunsinger, J. Allen, M. - Klastrup, L. (eds): The International Handbook of Internet Research. Heidelberg: Springer Verlag

Kálmán, Zs., Könczei, Gy. (2002). A Taigetosztól az esélyegyenlöségig. Osiris

Kemény, P. (2015). Lépések a kiszámíthatóbb, emberséges foglalkoztatás felé. A foglalkozási rehabilitáció és a HR In: Soltész, A. (szerk.) Munkavállalók és munkáltatók a megváltozott munkaképességüek foglalkoztatási lehetöségüek foglalkoztatási lehetöségeiröl, esélyeiröl, proAbility, 93-109.

Király, G., Dén-Nagy, I., Géring, Zs., \& Nagy, B. (2014). Kevert módszertani megközelítések. Elméleti és módszertani alapok, Kultúra és Közösség, 5(2), 95-104.

KSH (2012). Megváltozott munkaképességüek a munkaerőpiacon, 2011. Budapest

Kun, A. (2009) A multinacionális vállalatok szociális felelőssége: CSR-alapú önszabályozás kontra (munka)jogi szabályozás, Ad Librum, Budapest

Kun Á. (2010). Munkahelyi szocializáció, beillesztés és alternatív foglalkoztatási formák a megváltozott munkaképességü egyéneknél, In: Juhász, M. (szerk.), A foglalkozási rehabilitáció támogatása pszichológiai eszközökkel, Typotex Kiadó, Budapest, 243-268.

Kurucz, O., Kemény, P. (2015) A megváltozott munkaképességü munkavállalók foglalkoztatását érintő jogszabályok és statisztikai háttér áttekintése In: Soltész, A. (szerk.) Munkavállalók és munkáltatók a megváltozott munkaképességüek foglalkoztatási lehetöségüek foglalkoztatási lehetöségeiröl, esélyeiröl, proAbility, 7-26.

Luetkenhorst, W. (2004). Corporate Social Responsibility and the Development Agenda. Intereconomics. 39 (3), 157-168.

Móré, M. (2012). Te csak beszélj, én könnyen beilleszkedem. A beillesztés kommunikációs összefüggései. A Virtuális Intézet Közép-Európa Kutatására Közleményei IV. évf. 2. sz. (No. 8.) A-sorozat 1. Szeged, 43-50.

Novak, M. (1996). Business as a Calling: Work and the Examined Life. The Free Press, NY.

Perrini, F. (2006). SMEs and CSR Theory: Evidence and Implications from an Italian Perspective. Journal of Business Ethics 67., 305-316.

Polyacskó, O. (2015). Korábbi kutatások a megváltozott munkaképességűek foglalkoztatásáról In: Soltész, A. (szerk.) Munkavállalók és munkáltatók a megváltozott munkaképességüek foglalkoztatási lehetöségüek foglalkoztatási lehetöségeiröl, esélyeiröl, proAbility, 52-62. 
Rayner, J. (2003). Managing Reputational Risk: Curbing Threats, Leveraging Opportunities. Institute of Internal Auditors Risk Management Series, Wiley,

Roberts, S., Heaver, C., Hill, K., Rennison, J., Stafford, B., Howat, N., Kelly, G., Krishnan, S., Tapp, P., \& Thomas, A. (2004). Disability in the workplace: Employers' and service providers' responses to the Disability Discrimination Act in 2003 and preparation for 2004 changes. (Letöltés: 2016.01.07.) (Web: www.webarchive.nationalarchives.gov.uk/20130314010347/http: / / gov.uk/asd/asd5/rports2003-2004/rrep202.pdf)

Sperkens, J. (2017). Growth through sustainability and partnerships, Céges Társadalmi Felelősségvállalás kultúrája Európában és Magyarországon Konferencia 2017.05.12. Budapesti Európai Ifjúsági Központ

Szabó, M., Kozicz, Á., \& Ottrok, V. (2012). AJB - 2618/2012 Jelentés (Letöltés: 2016.02.29.) (Web: http://tamogatoweb.hu/ekonyvtar_pdf/fogyatekossaggal-elok-foglalkoztatasihelyzete.pdf)

Tardos, K. (2015). Halmozódó diszkrimináció kirekesztés és integráció a munkaerőpiacon. Szeged: Belvedere Meridionale.

Waddock, S., Bodwell, C., \& Graves S. (2002). Responsibility: The New Business Imperative. The Academy of Management Executive 16(2), 132-147.

Watts, P., Holme, L. (1998). Meeting Changing Expectations - Corporate social responsibility. Geneva, WBCSD Report.

Törvények, kormányhatározat

2007. évi XCII. törvény a Fogyatékossággal élő személyek jogairól szóló (ENSZ) egyezmény és az ahhoz kapcsolódó Fakultatív Jegyzőkönyv kihirdetéséről

2011. évi. CXCI. törvény a megváltozott munkaképességű személyek ellátásairól és egyes törvények módosításáról (Mmtv.)

1025/2006.(III.23) Kormányhatározat, A munkáltatók társadalmi felelősségének erősítéséről és ezt ösztönző intézkedésekről

Internetes hivatkozások

Net1: vállalat honlapja Letöltés: 2017.01.01.-2017.10.08. többszöri)

Net2: anyavállalat honlapja Letöltés: 2017.01.01.-2017.08.01. többszöri)

Net3: www.ec.europa.eu/growth/industry/corporate-social-responsibility/index_en.htm Letöltés: 2016.01.11.

Net4: http://mef.forum.hu/index Letöltés: 2017.04.16.

Net5: www.salvavita.hu ketöltés: 2016.01.19.

Net6: http://www.segitovasarlas.hu Letöltés: 2017.05.26.

Net7: http://hotelpanda.hu/ Letöltés: 2017.05.26.

Net8: https://www.hatpottyos.hu/home Letöltés: 2017.05.26.

Net9: http://neo-interactive.hu/ Letöltés: 2017.05.26.

Net10: https://www.kockacsoki.com/ Letöltés: 2017.05.26.

Net11: www.//fbm.hu Letöltés: 2016.01.10.

Net12:http://www.menszt.hu/tudnivalok_az_egyesult_nemzetek_szervezeterol/fenntarthato_f ejlodesi_celok Letöltés: 2017.08.01. 
Net13: https://www.youtube.com/watch?v=tESU11KIoFE Letöltés:2017.10.20.

Net14: http://artman.hu/kik-vagyunk/rolunk/ Letöltés: 2017. október 14.

Net15: http://www.suhanj.hu/ Letöltés: 2017. október 14.

Net16: https://sokszinusegikarta.hu Letöltés: 2017. október 14.

\section{Függelék}

1. sz. függelék: ENSZ globális fejlődési célok (forrás:

http://www.menszt.hu/tudnivalok_az_egyesult_nemzetek_szervezeterol/fenntarthato_fejl odesi_celok)
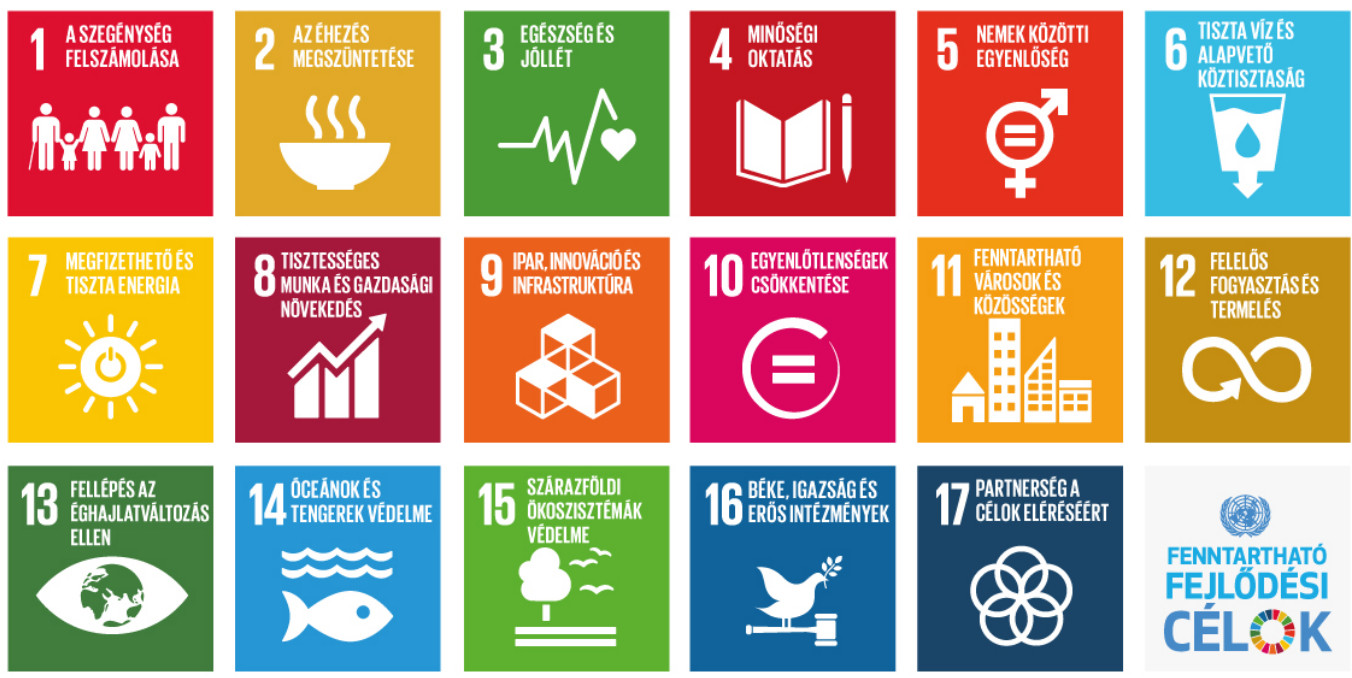

(7)

FENNTARTHATÓ FEJLÓDÉSI CÉLOK

2. sz. függelék:Fenntarthatósági témák fontossága a vállalat érdekeltjeinek körében (a változás értéke 2016-ban az előző évihez viszonyítva). forrás: saját szerkesztés a vállalat Fenntarthatósági Jelentés 2015 és 2016 alapján

\begin{tabular}{|l|l|l|l|l|l|l|l|l|l|}
\hline & Szabályozó & $\begin{array}{l}\text { Beszállító, } \\
\text { partner }\end{array}$ & $\begin{array}{l}\text { Civil } \\
\text { szervezet }\end{array}$ & Munkatárs & $\begin{array}{l}\text { Jövő } \\
\text { generáció }\end{array}$ & Befektető & $\begin{array}{l}\text { Helyi } \\
\text { közösség }\end{array}$ & Média & Ügyfél \\
\hline A & $2.0(-1.0)$ & $3.1(+0.3)$ & $3.0(-0.1)$ & $3.1(+0.3)$ & $2.8(+0.2)$ & $2.5(+0.2)$ & $2.3(-0.2)$ & $3.4(+0.7)$ & $2.6(+0.1)$ \\
\hline B & $3.0(-0.5)$ & $3.0(+0.1)$ & $3.2(+0.2)$ & $3.2(+0.7)$ & $2.6(0)$ & $2.5(+0.2)$ & $2.5(-0.1)$ & $3.2(+0.8)$ & $2.8(+0.3)$ \\
\hline C & $2.0(-0.5)$ & $2.6(+0.1)$ & $3.2(+0.6)$ & $2.7(0)$ & $2.3(-0.4)$ & $1.9(-0.5)$ & $1.9(-0.5)$ & $2,5(+0.2)$ & $2.2(-0.1)$ \\
\hline D & $1.0(-1.5)$ & $2.7(+0.3)$ & $3.0(+0.2)$ & $2.4(-0.2)$ & $2,2(-0.4)$ & $1.6(-0.9)$ & $2.0(-0.2)$ & $3.0(+0.7)$ & $2.1(-0.1)$ \\
\hline E & $3.0(+0.5)$ & $3.0(+0.5)$ & $2.5(+0.6)$ & $2.2(+0.1)$ & $2.1(+0.1)$ & $1.8(-0.5)$ & $1.8(+0.1)$ & $2.2(+0.5)$ & $2.2(+0.3)$ \\
\hline
\end{tabular}


3. sz. függelék CSR tevékenységek fogyatékosokkal, megváltozott munkaképességüekkel kapcsolatban (forrás: Bene, 2016. 37.o.)

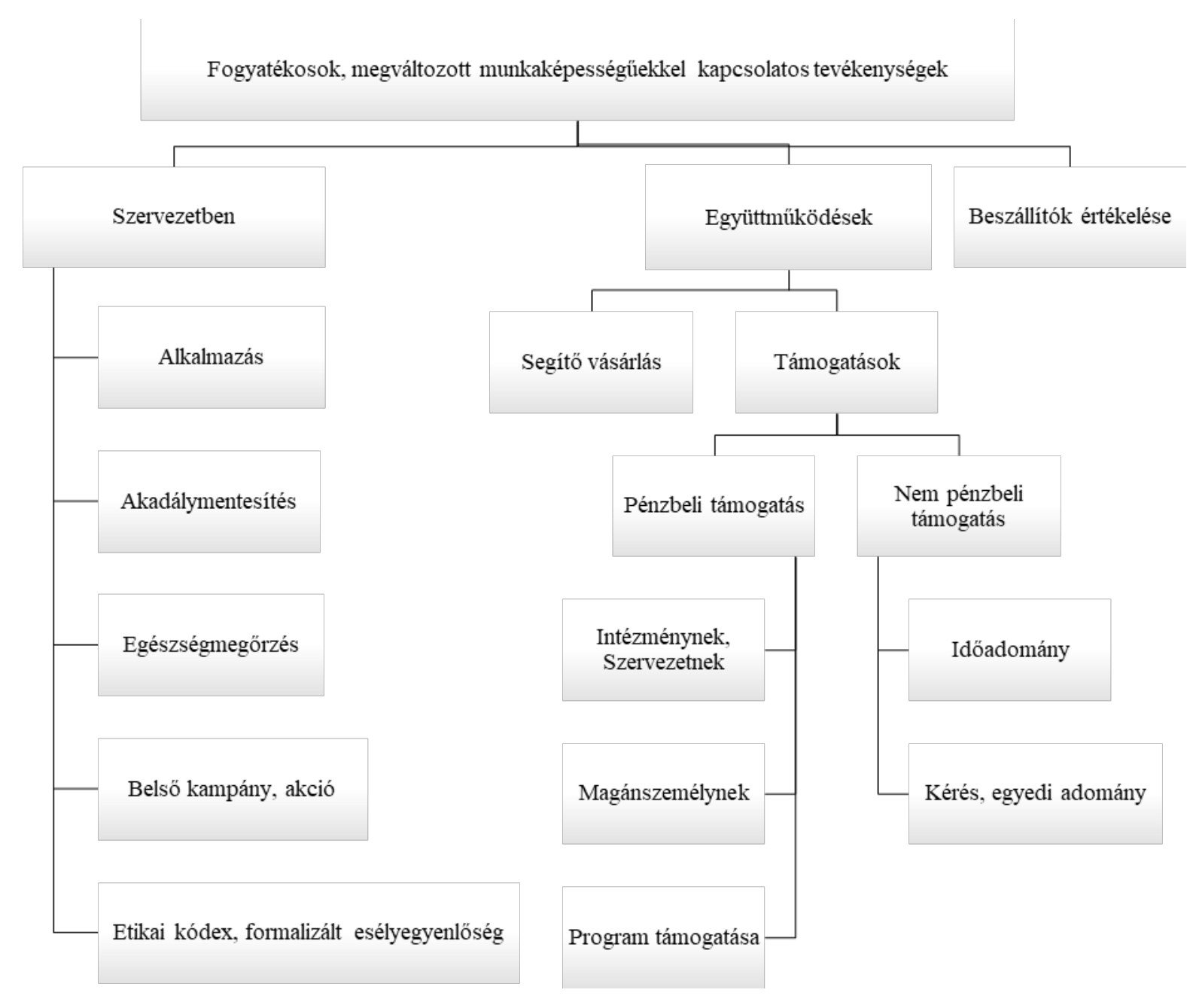

